\title{
The Escalation of Gambling in Papua New Guinea, 1936 to 1971: Notable Absence to National Obsession
}

\author{
Anthony J. Pickles \\ University of East Anglia \\ a.pickles@uea.ac.uk \\ 0000-0001-7524-602X
}

This work was supported by the British Academy under Grant pf160081 and the ESRC under Grant $\mathrm{ES} / \mathrm{G} 012814 / 1$.

No potential conflict of interest was reported by the authors.

Future Papua New Guineans (PNG) start gambling from the 1880s. Gambling was then made illegal (for them but not for their colonisers). It takes off during World War II, becoming ubiquitous knowledge by the late 1970s, just after Papua New Guineans achieve independence from Australia. As incidence accelerates gambling relationships proliferate until they plateau at saturation point. This exciting, liberating, unpredictable cloud of activity became a threat to the prospect of an ordered, advancing independent modern nation-state. PNG legislators responded by banning playing cards completely. This is suggested as evidence of an 'escalation' because gambling became something new, a vehicle for imagining the nation as a truly connected whole through this relational technology, even if the image was an uneasy one. As the escalation occurred the acceleration plateaued once new recruits dried up and as economic development failed to materialise, revealing some useful socio-material guardrails for an anthropology of escalation.

Gambling adoption, Australian colonialism, World War II, gambling law, Melanesia 
"We'll gamble money -

Women, money and houses -

With women, men or visitors

In this house of ours."

Oh, it was rudely fantastic!

(“A Poem about Gamblers New Guinea Style” by Jack Lahui, 1975.)

Card gambling is virtually omnipresent across Papua New Guinea (PNG). It is the primary social afternoon and evening activity despite strong Christian and government opposition, so much so that gambling is often the pre-eminent way that money changes hands. Not a day goes by without half of the population of my rural field site in Simbu Province sitting down to gamble for at least three hours. Along the roads, at the junctions, and in the urban slum settlements where I have also worked, gambling is even more intense. Gambling passes the time, and gives people access to money, packet noodles, rice, soft drinks, cigarettes, beer and betel nut. For primarily subsistence horticulturalists like my Simbu informants gambling means encountering valuables and consumer goods that represent an all-powerful heterochthonous economy that they, on the periphery, cannot hope to master (Pickles 2014a). "If we don't gamble, we don't see the face of money," I was told more than once.

I can find no evidence that gambling existed in what is now Papua New Guinea before colonisation and early anthropologists point out that nothing resembling gambling happened before (Seligman 1910; Mead 2002 [1968], 55; 1956, 182; Hogbin 1963, 69). The following is a historical account not of gambling's first arrival but the period when gambling went from a localised curiosity to a national staple. It illustrates the intimate relationship between the acceleration of gambling and the economics of the colonial project as carried out by Australia. The economic peculiarities were pivotal to the mammoth transformation taking place, which was why gambling became a conventional avenue for exploring new economic potentialities. I tease out qualitative changes that coincide with scale shifts in gambling 
activity across an otherwise diverse ethnographic context among peoples who were all nonetheless novice gamblers.

Following the neat terminology laid out by Højer et al (2018) and Højer (this issue) I brand the quantitative increases in both gambling participation and in gambling activity as accelerations. Gambling moves wealth quickly in successive rounds, accelerating or inflating the quanta of transactions people experience, facilitating what Strathern called relational inflation (Strathern 1999, 105-06). The practice of gambling is new to people and in that sense a qualitative change occurs while gambling participation accelerates. I draw attention to the new connections made between people who already transacted with each other in different ways but now gambled together, and the wholly novel relations created through gambling. The acceleration of transactions is also characterised by an intensification of connections created by gambling participation. One can imagine novice gamblers as like old brain cells growing new synaptic connections between them, suddenly capable of firing in more directions and new patterns through their shared connection. The acceleration in the incidence of novel gambling means a logarithmic densification of potential gambling relations. This is a broad scale example of what Højer et al (2019) call an escalation, i.e. a qualitative change resulting from a quantitative acceleration. In evidence I offer that the gambling explosion is diagnosed by some of the first ethnic Papua New Guinean legislators as a new and potentially dangerous affliction affecting their constituents as they adjusted to the new national scale economic reality. House of Assembly members representing the worstaffected constituencies respond by going after cards rather than gambling, reasoning that without the negative relational technology of cards, attention would turn toward creating the positive relations required to build a sovereign nation state. A bill to ban playing cards becomes the first legislation ever to be proposed (and passed) by an ethnic Papua New Guinean. There are therefore two distinct qualities distinguishing the 'escalation' from the 
quantitative acceleration: 1) the densification of relationships through gambling reaching a point of saturation, and 2) the concomitant fostering of a new imaginative register within which all ethnic Papua New Guineans can be conceptualised together as inveterate gamblers.

The following is not however a story about the invasion of an alien trait so much as it is about a creole culture developing underneath houses, in back rooms and engine rooms, cook houses and labourers quarters, bubbling under the surface until it could no longer be hidden. This is crucial to understanding gambling as a qualitative escalation. Gambling didn't just replace existing functional practices (storytelling, ritual preparations, guard duty), the adoption of gambling correlated with a complete upheaval in the orientation of Melanesian political economies. In Max Gluckman's (1963) terms, gambling was one face of a true revolution and not a superficial rebellion. One utility of escalation as a conceit in this case is its capacity to describe a growing constellation of forces without implying any hierarchy of cause (see also Spyer, this issue). Identifiable causes contributing to Papua New Guineans adoption of gambling include wage-labour and cash cropping, religious upheaval, and indigenous cosmologies that value a prospecting mentality, to name but a few. But here the progressive interplay of causes and their recursive feedback is more illuminative than either ranking causes in terms of ultimate importance or attempting to determine the ultimate sources of named causes. The effect is that of a churning pool in a rushing river. Escalation in the present case cannot be pinpointed to a single act but rather proliferates, bubbles and froths into a qualitatively different state from the trickle with which it began.

The theme of escalation has the added advantage of not specifying the starting scale of the phenomenon under investigation, stipulating only that whatever its qualitative effect, upscaling must increase quantitatively from smaller, lower or less to larger, higher or more. Among the contributions to this special issue, the following account operates across the broadest geographical expanse and the longest time period. Covering longer than a human 
lifespan (1880 - 1975) and spanning mountains, swamps and seas means exploring the outer limits of escalation's utility as a concept as Elliot (this issue) explores its innermost limits by interrogating the minutest human scale imaginable as an escalation. While I use materials often gathered from ethnography and employ my ethnographic experience to guide my analysis, the escalation I describe is an artefact of my own scholarly analysis insofar as it attempts to draw together numerical data and qualitative descriptions of rupture into a single geo-historical narrative of escalation. Usable data on gambling adoption is not usually accompanied by rich ethnography (or vice versa), and therefore generalisation is a hazardous enterprise, especially so across contexts known for their variability. I justify the move by appealing to the national scale debate in the PNG House of Assembly that occurs at the culmination of the escalation. It strikes me as appropriate to adopt a geo-historical perspective precisely because this was the scale being called into being by these pioneer politicians as they banned playing cards.

\section{On Not Corrupting "the Natives"}

Australians lose more money gambling than any other country in the world (The Economist, February 9, 2017). Their love affair with gambling dates to the gentry-backed horse racing tracks of the early colonies and was cemented during the Australian gold rush that began in the 1850's (O'Hara 1988). Most Australian settlers were of European extraction and familiar with European gambling, but there was also traffic from other colonies, most notably from China, which of course has its own long and rich history of gambling. The Sydney Morning Herald describes a bustling Sydney full of Englishmen, Americans, Germans, Irishmen, Chinese and Papuans, everyone "possessed by the demon" of gambling (December 1, 1855). Papered over with images of ethnic European gentlemen horse-breeders and rugged 
frontiersman and miners, the development of Australian gambling actually occurred in a multi-ethnic, Pacific colonial context. It was dominated by ethnic Europeans and contoured by the enlightenment-derived notion of racial hierarchy, but as is so often the case, during illicit leisure normalising hierarchies were deferred, and especially so among the poor.

A system of indentured labour and slave raiding took people from the island of New Guinea and its neighbours to Australian sites of production or resource extraction that included gold and copper mines, sugar and copra plantations and the pearl-fishing industry. Leading up to the Second World War the records suggest a great variety of gambling games occurring in geographically isolated pockets. In addition to the standard lotteries, totalizers, housie housie (bingo) and betting on horses, the Government Secretary for New Guinea restricted or completely prohibited "Art Unions ... Chocolate Wheels, Hoop-la, Knockem, Roll Down, Race Game (wooden horses moved by winding or throwing of dice) ... Under and Over, Troy, Two-up, Head and Tails Dice, Hazards, Fan Tan, Yankee Grab, Tray-BitPeter, Fan-Tan-Troy, Pak-a-pu, Troy, Heading Them, Sin-ki-Loo, Baccarat, Ins and Outs, Roulette, Crown and Anchor and Race Game (not mechanical winding).” (Memorandum C.A. 37/2/3, Jan 12, 1954). Amongst these are games that originate from China, Australia, Europe and the United States.

The Commonwealth administration of Papua (the southern half of the modern country) became stridently against gambling and alcohol consumption by locals. After watching their "masters" gambling, Papuans took up gambling when they went off-duty. To keep their servants fresh for work a law was passed in 1906 preventing Papuans from gambling after 9pm, and then in 1907 a new law forbade them from gambling at all (Wolfers 1975, 39). Their argument was that "neither card-playing nor drinking were native customs" (Murray 1925, 71). 
The general pattern of gambling bans can help us to understand the qualitative difference that gambling was thought to herald (Pickles 2019). Bans on gambling were used by communists in China and Vietnam, Rwandan revolutionaries, and English Parliamentarians to mark a break between new and old orders through everyday practice. Renaissance English kings and king Menelik II of Ethiopia are examples of the opposite: elites who felt threatened either externally or from below and sought to shore up control through a prohibition on gambling. Whether to mark a change of regime or secure one's position, the suppression of gambling among the masses was an attempt to refashion them into compliant subjects. The Maoists argued that gambling was a sign of the corrupt mentality of landlords that was infecting the virtuous peasantry. In instituting their prohibitions Britons often blamed their gambling on the influence of the French, the British being otherwise innocent. Arguments against gambling imply that elites thought the correct, pure, natural, or original state of the people was to be free of gambling, and they were corrupted. This corruption had to be forestalled lest it delegitimize them.

Religious edict has also been central to the prescription of gambling. Mughal emperor Aurangzeb in India (circa 1659), the Sokoto Caliphate in nineteenth century Nigeria, and Puritans in Massachusetts Bay (circa 1646) turned their desire that people live by religious texts into legal prohibitions on gambling (Reefe 1987, 61; Schwartz 2006). Puritans argued that gambling was wasteful and unproductive and therefore inimical to the purpose of God, while Aurangzeb attempted to stamp out a social evil as defined by the Quran. Whether these attempts appear optimistic in the extreme, or not, it should be noted that gambling appeared dispensable. The observation runs counter to contemporary casual observations that gambling is an irrepressible manifestation of basic human instincts. Australia at the turn of the twentieth century was instituting the White Australia Policy, which among other things blamed excessive gambling upon its non-white residents. Ire was directed predominantly at 
ethnic East Asians and their gambling houses, but Pacific Islanders were also the subject of abuse for their supposed corruptibility. Dominion over Papua and later New Guinea passed to Australia in 1906 and 1914 respectively.

\section{Lieutenant Governor and Chief Judicial Officer of Papua (1908-1940) Sir Hubert} Murray's attitude to Papuan gambling was a logical extension of this thinking. He thought that those who were accustomed to European ways were more inculcated than those whose crimes were consistent with customary beliefs (Dinnen 2001, 21). The Papuan Villager, an official magazine written in English but (as the title suggests) apparently aimed at Papuans, explained horse racing and betting with its signature blend of condescension and righteousness in time for the Port Moresby Race Club's big annual meeting. It is to my mind the clearest articulation of the Australian colonial consensus on gambling.

\footnotetext{
You may ask why the white men are allowed to make bets while the Papuans are forbidden to do so. The reason is that white people usually have more sense in betting than Papuans have. They know when to stop, and don't throw away all their money. It is the same with strong drink. White men usually know when to stop; but Papuans might not know, and they might get up to mischief or cause trouble. That is why white men are allowed to bet and drink whisky, while Papuans are not. (The Papuan Villager, October 1930)
}

In the case of colonial Papua the pristine innocence of the masses is racialized into primitives who are unable to control themselves and the worldly white (protestant) male who must bear the burden of supervising their activities.

The first conviction for gambling occurred near Port Moresby in 1907, but in time prosecuting gambling became a tedious routine for Patrol Officers (CAARTP 1906-7). It would not help the colonisers in their attempts to suppress gambling that police barracks and prisons were breeding places for gambling, including meticulous drill instructors who were nevertheless notorious for a love of card gambling (Hides 1936, 3; Kituai 1998, 253). On 
patrol police would conduct regular furtive gambling sessions away from European superior officers (Kituai 1998, 166). One exasperated officer thought his Papuan police had "almost a madness" for card games, and they would boisterously encourage villagers to join them in their carrier's house or camp for gambling sessions (Cheesman 1935, 139). In fact, it was the machinery of colonisation in the form of plantations, barracks, prisons and wage work that facilitated initial growth in gambling.

\section{Raising the Stakes}

Gambling arrived on several fronts and in different forms but because plantations and mines were generally at a distance from Islanders' home communities, because the proportion of people who left New Guinea was small and tended to be concentrated on specific communities, and because gambling was sanctioned by their colonisers the transmission of gambling was limited. If things had continued in the same glacial pattern as I have described for the period 1880-1935, then gambling may never have become a national pastime. Instead, as Chart 1 shows, there was a sharp acceleration in gambling convictions in the Territory of New Guinea, beginning in the mid 1930's and eventually stabilising at around two thousand convictions a year in the early 1960s, a hundred-fold increase on pre-war figures and a growth rate of nearly thirty per cent a year for twenty five years. ${ }^{i}$

\section{[Chart 1 near here]}

There are several reasons gambling convictions in New Guinea might rise in the runup to and following the Second World War that have nothing to do with the underlying prevalence of gambling. These include changes in police policy such as those imposed by the administrative unification of Papua and New Guinea, an increase in police presence, an expansion of the state and its encountering new populations, increased willingness to report 
crimes and growing awareness of the law. Nevertheless, secondary qualitative evidence supports the impression that underlying gambling rates were broadly reflected by conviction rates. Maps 1, 2, and 3 show how descriptions of gambling in print increase during this period, and Map 3 indicates that these neatly clustered around newly built roads. Crucially there was already a stringent anti-gambling policy in force before the rate of convictions soars. In addition, contemporaneous commentary from a range of sources simultaneously and independently comment upon the upsurge in gambling. The wealth of supporting secondary evidence documenting an increase in gambling is complemented by my own fieldwork experience and interviews, during which native New Guineans regularly recall the time when gambling took off in their communities. I begin though by looking at the gambling that took place among the soldiers who fought their way across the country.

[Maps 1, 2 and 3 near here, see bottom of document]

During World War II Australian and United States servicemen were reported in the Australian press as heavy gamblers. Some soldiers operating as bookmakers made thousands of pounds during their service. Others racked up losses of up to $£ 380$ a night on games of "two-up," dice, or "in-and-outs" run by fellow soldiers (News (Adelaide), June 2, 1945). After WW2 there is a popular understanding among white Australians that Papua New Guinean gambling was the "sordid legacy" of the troop presence. The Morning Bulletin newspaper reported Reverend Cocks, Australia and New Zealand secretary for the London Missionary Society addressing a congregation in Queensland and claiming that

The most serious vice which the Papuans had learned from the troops was gambling and they now understood the power, and not the value, of money. When the troops were on the island money streamed into the Papuans' hands and, with nothing to purchase, they soon learned to gamble. "I have seen a group of school age children playing 'two-up' with the village policeman looking on," he said, "and I know that when I left the policeman joined in the game." (Morning Bulletin (Rockhampton, Qld), July 25, 1946). 
Actually, the missionary Reverend V.H. Gough Sherwin retorted, the locals "could show the white population a few points on gambling before the war' but he admitted that the troops "sharpened the natives' gambling instincts, particularly in remote parts." (News (Adelaide), July 15, 1947).

In Milne Bay locals were removed from their villages at the outset of war, and these were destroyed, along with much of their means of subsistence. During this period the people were resettled in camps that lacked cultivable land and they persisted on army rations. Upon return, there was a shortage of tools, seed yams and taro suckers, but there was a ready supply of imported food at the stores. This they paid for with the compensation they received from the Allies, as well as the accumulated wages of those men who had signed on to work for the army. Much of people's increased leisure time was therefore spent gambling, a practice introduced during the small mining boom, but increased by association with army personnel (Mair 1948, 222). Likewise, at the other end of Papua and New Guinea, a returning Margaret Mead found the Manus islanders had taken to calling the War "the time without taboos." Gambling had reportedly been kept rigidly in check before WW2, during which a large army base had been located on the main island $(1956,182)$. Many men who had worked in the war effort had lived an exciting life "disporting themselves on every moonlit night" (Hogbin 1947, 18). When they returned home all they could do was gamble, so that was all they did. Boredom was exacerbated in areas where traditional courting dances had been banned as a result of mission influence. Without the education and amenities provided for labourers in wartime, plantation and goldfield labourers took to gambling more intensely, with up to several pounds won and lost each night at the new game "lucky". Losers informally mortgaged months of future earnings (Hogbin 1951, 190).

From this point on "lucky", otherwise known by its Tok Pisin names laki and tri-lip, dominates the literature. Donald Laycock postulated that the game became nationally popular 
when people learnt a game from American and/or Australian G.I.s based in Papua New Guinea during WWII (1972, 476). Australian and particularly American soldiers often built up relationships with New Guineans that were far more intimate than the typically distant white colonisers. Large ethnographic variations between forms of laki are now common (cf. Mosko 2012 vs. Pickles 2019), but early descriptions are relatively uniform from the Highlands to the Sepik to New Britain (Brandewie 1967; Laycock 1966, 1967). This contrasts to the many and varied games described before the War and speaks to a connected national community of gamblers.

After WW2 laki became the dominant game on plantations (see Hardie 1962, 2), which were increasingly and soon after predominantly populated with Highlanders from the mountainous interior of New Guinea, which was not visited by ethnic Europeans until 1931. Populous societies were encountered in what had been thought to be pristine wilderness, doubling national population estimates almost overnight. The Highlands became a profitable new labour frontier for their coastal plantations as well as prime sites for coffee and tea plantations. The onset of World War Two stifled attempts to utilise the population, but soon afterwards the Highlands Labour Scheme was in full swing. It was therefore laki that broke out as the first major game on the new Highlands labour frontier (see Pickles 2014b).

In urban areas meanwhile despondent young men were seeking out the entertainment of a "cut-throat game called 'lucky"” with stakes of three-pence and sixpence (Groves 1957, 216; Belshaw 1957, 85). In peri-urban Hanaubada different kinds of gambling had been present and punished for fifty years and "gambling schools" had become routine, held "secretly from house to house, or, if the weight of authority is too great, in the open grasslands behind the village" (Belshaw 1957, 177). Mekeo labourers from up the coast living in Hanaubada would join forces with locals in collaborative games and up the stakes to 
thrilling levels (218). The secret gatherings attracted undesirables, including "unprincipled half-castes and Europeans" (178).

Across plantations, rural and urban locales a national swelling of gambling connects formerly disparate people, with conflicting dynamics in complex interplay across the changing colonial language. This is an unmistakably Papua New Guinean phenomenon, an emergent national pastime developing as the whole population came to know the main gambling game. In a country riven by extreme linguistic and cultural diversity, the common language of gambling was a factor in a qualitative shift toward mutual intelligibility.

\section{Post-War Prohibition}

In this section I claim that both Australian and later Papua New Guinean policy responses to a population increasingly saturated with gambling further contour the qualitative change of scale in the national relationship to gambling. In a letter sent to Australia's Minister for External Territories Percy Spender, Rev. Chenoweth of Kavieng relates that he had tried to bring up the matter of betting on Australian horse racing by post with his local District Officer, but was told that because the New Guineans were gambling outside of the Territory, nothing could be done. This chain of correspondence culminates in one informal and one formal report on gambling in Papua and New Guinea over the coming decade (in 1954 and 1957 respectively). Chenoweth also provokes a rift between Canberra's paternalistic attitude towards apparently fragile natives and the Administration in Port Moresby. The Department of Territories is particularly embarrassed by a story that surfaces in the British newspaper the Daily Telegraph reporting a “£5000 WIN FOR JUNGLE NATIVE” who, despite the sensationalist title, turns out to be an assistant entomologist living in the industrial city of Lae

(Daily Telegraph (London), April 18, 1958). Canberra wants gambling suppressed for public 
relations reasons while Port Moresby are reticent to bring in any new discriminatory legislation when the winds were shifting towards self-governance (Gambling by Natives 1950-1961). Nothing is done, and faced with the escalation of gambling, enforcement is all but ended.

That is until 1964-1965 and the newly established House of Assembly, a body that would bridge colonial government and the fully independent PNG Parliament. The very first law introduced by an ethnic Papua New Guinean to the House was a bill to end the sale and manufacture of playing cards. It was championed by Highland members aghast at how seriously affected their constituents were. "People fight and steal and break into houses all because of cards. District commissioners and police officers are incapable of controlling card playing and the trouble and fights caused through it." Said Member for Wahgi Kaibelt Diria in introducing the Bill (TPNGHAD 1965, 813). Ethnic European lawmakers met it with disbelief, but none ultimately wanted to stand in the way of Papua New Guinea's first indigenous piece of legislation, and it was passed (TPNGHADSH 1969, 1138). Reading the initial debate and the ensuing repeal debates today, they jump out of the page, bristling with heartfelt concern and political sensitivity. There are three sides, Highlanders and their New Guinea supporters, Papuans, and Europeans (TPNGHAD 1965, 813-19).

Concerns voiced by ethnic Europeans in the House of Assembly assume that gambling is a part of human nature, and that once known it will bubble up in whatever form is materially available. The Highland representatives were speaking in the midst of the ubiquitisation of gambling in their constituencies and somewhat tragically seem to assume that the government can by force of law redirect the activities of its subjects with absolute certainty. Each Highland Member tells the House that their people have called for the government to do it, according to their representatives they had therefore demonstrated that they were ready to be directed. Some Papuan Members emphasised personal responsibility 
and the analogy between the dangers of liquor and cards (TPNGHAD 1965, 815), but one Highlands representative, Siwi Kurondo countered in the name of national unity:

In the Highlands there are many Papuans and they play cards. If, suddenly, a man from Papua gets killed because of gambling at cards my people might say that all the Papuans must be driven out of our area. I feel that this Bill must be passed and then we can all sit down together and be friends. (TPNGHAD 1965, 818)

From the debate it is clear the wholesale adoption of gambling was a genuine phenomenon. Political representatives taking up a new role in representing people beyond their own kin or tribal network imagined a new constituency connected by their proclivity to keep gambling. The people in that new role tried to act upon all of Papua New Guinea for the first time by going further than any colonial government had gone before by banning cards for everybody. In this way they tried to remove the relational materials producing negative connections to create space for the accumulation of positive modernist relational technologies such as books, roads and trucks.

The pessimistic Europeans in the House of Assembly have been proven correct; government could not prevent the people from gambling, and they could not elevate average Papua New Guineans into global citizens. Gambling did not go away, even if Highlands Members later claimed there had been a diminishment. The continuation of gambling under prohibition demonstrates not that there is a natural capacity to gamble that cannot be contained, as the Australians saw it, but that the conditions created by imported institutions and the forging of novel economic configurations has resulted in the familiar realisation that the power of government is partial and blunt, lacking in the valued skills of persuasion.

Ethnic European members also correctly predicted an embarrassing international news story. Australian newspapers occasionally tittered about the illegality of playing with cards in Papua since the 1930s, but the whole world seemed to get a laugh out of a ban on 
cards themselves. When a new law that would repeal the ban on cards was floated in 196970, a major argument was that the world was ridiculing them. During the repeal debate Members emphasized the new kinds of gambling created by those people who were struggling to get hold of cards. The most popular was a game played with a matchbox, designed to be as close to lucky as possible. Just outside of the parliament one Member claimed to have found a business card whose reverse was inscribed as the six of spades and that children made playing cards from their exercise books. Members said they saw people playing cards at the international airport (TPNGHADSH 1969, 1135-43). In direct contravention of the law, entrepreneurs were travelling to port cities, particularly Lae, and buying cards from foreign ships, and then transporting them home at huge profit (see also Watson 1971, 2).

In an inversion of the arguments of other Highlands Members, the Member for Sinasina claimed that the law was both ineffective and stopped the proper exchange of wealth between the haves and have-nots (TPNGHADSH 1969, 3110-17). He admitted he is a gambler, and so are all the people on the Council committee where he is from, and so is their President. Gambling with the haves is what the have-nots do to get a chance to get hold of more money, he says. At last, he reminds the House that he knows many Members there present who can't resist joining in a game of cards when they see one. Having not provided alternative and accessible means of blending traditional skills and the incoming money economy, gambling became one of the very few ways people could conceive of getting a decent proportion of the new valuables. Once viable, gambling became a pursuit in itself, and under conditions where industrious people are consistently demoralised and their traditional modes of gaining success undermined, it is easy to see why the presence of this new thing called gambling can appear the only thing to do. The House of Assembly debates over these 
years, whether they argue for or against the prohibition of gambling, demonstrate the growing national sense of transactional interconnectedness emblematised by the growth of gambling.

\section{Conclusion}

The adoption of gambling in what became PNG occurred through a knot of different dynamics interweaving. An Australian nation of gamblers could not tolerate gambling in its colonial other, forcing it underground. The agents of administration taught villagers so that they would lose to them, while institutions brought together bored young men who were fed and had disposable wealth. Others like American soldiers disturbed racial lines and played and showed gambling to native New Guineans. Global war, the Highlands Labour Scheme and infrastructural developments intensified these conditions and, along with the anti-colonial struggle, opened Papua New Guinean eyes to their collective commonalities.

Gambling took off in the multi-ethnic spaces at the frontiers of inequality created by capitalism under colonialism. Vast movements of exogenous and indigenous people, the suspension of subsistence activity and the concentration of exogenous capital that resulted from global war accelerated participation in gambling. The disparities in wealth that were accentuated by wartime and colonialism were accelerated once more by the discovery of a vast and cheap pool of labour when the Highlands was opened up. Gambling became a key driver in ethnic Papua New Guinean reorientation toward imported wealth items and the activities that brought access to them.

Gambling represents an acceleration of transactions, a means to engage with valuables more frequently, and more intensively than people otherwise could. Round after round the money moves, the highs become lows, the lows become highs, and your senses are heightened like the player in Lahui's euphoric poem; the importance of the money is 
diminished by the giddiness of movement (see also Puri, this issue). The acceleration of gambling convictions for the period 1936-1968 appears roughly linear, but during that time a chart displaying the number of possible gambling relationships would look much different. Every new gambler produces any number of new potential gambling relationships, and so the densification of relationships would start off relatively shallow, rising steeper and steeper and then plateauing at the point of saturation when gambling becomes commonplace. This plateauing represents the qualitative difference, gambling becoming unavoidable, and it is identified by Highlands House of Assembly Members as an existential threat and by a poem published the year of Papua New Guinea's Independence. In addressing gambling, Papua New Guineans surfaced and fashioned their own national interests, forging a national crisis and with it the grounds for my own attempt at a geo-historical narrative of escalation. Assembly Members rightly perceived that exogenous goods like cards encoded and brought into being both positive and negative new types of relation, and naturally they tried to banish the inhibitive ones. It was too late to do so, giving the lie to the perceived power of the state. The acceleration led to two qualitative shifts a) an inflation in the very velocity of transactions (hence turning the acceleration, so to speak, into "a state" where everything is speeded up and intensified) and b) created a space for imagining all Papua New Guineans as one constituency.

The acceleration tailed off. Gambling lost its promise. It began to take forms that reflected relations between different Papua New Guineans more than an orientation toward an imposed economic system (see Pickles 2019). Papua New Guinea joined Australia as another nation of gamblers. In part the end of the escalation was etched into the acceleration from its beginning: as the country came to know gambling, new recruits became fewer. And as economic development stuttered, access to the materials, incentives and potential gambling partners needed to gamble in primarily subsistence farming areas reached a plateau that has 
remained largely in place until today. Socio-material constraints on the upper limits of an acceleration here result in an escalation that is at the same time a plateau. I offer this example as what I hope is a generative conceptual constraint, with potential to tell us something about escalation as a socio-cultural readjustment to- or incorporation of accelerating phenomena.

\section{References}

Belshaw, Cyril S. 1957. The Great Village: The Economic and Social Welfare of Hanaubada, an Urban Community in Papua. London: Routledge \& Kegan Paul.

Brandewie, Ernest. 1967. "Lucky: Additional Reflections on a Native Card Game in New Guinea.” Oceania 38 (1): 44—50. doi:10.1002/j.1834-4461.1967.tb00933.x.

Cheesman, Evelyn. 1935. The Two Roads of Papua. London: Jarrolds.

Commonwealth of Australia Report to the Council of the League of Nations on the Administration of the Territory of New Guinea (CARCLNATNG). 1929-30; 1930-1; 1931-2; 1932-3; 1932-3; 1933-4; 1934-5; 1935-6; 1936-7; 1937-8; 1939-40; 1946-7; 1947-8; 1948-9; 1949-50; 1950-1; 1951-2; 1953-4; 1955-6; 1956-7; 1957-8; 1959 -

60; 1960-1; 1961-2; 1962-3; 1963-4; 1964-5; 1965-6; 1966-7; 1967-8. Canberra: Commonwealth of Australia.

Commonwealth of Australia Annual Report of the Territory of Papua (CAARTP). 1906-7. Canberra: Commonwealth of Australia.

Dinnen, Sinclair. 2001. Law and Order in a Weak State: Crime and Politics in Papua New Guinea. Honolulu: University of Hawai'i Press.

Gambling by Natives - Papua and New Guinea [1 cm]. 1950-1961. National Archive of Australia: A452, 1957/3521

Gluckman, Max. 1963. Order and Rebellion in Tribal Africa. London: Cohen and West. Groves, Murray. 1957. Sacred Past and Profane Present in Papua, Quadrant 1 (3): 34—48. No doi.

Hardie, P.A. 1962. Patrol Report to the Mitnande Census Division. Patrol Report No.3 of 1962-3. Mandeville Special Collections Library, University of California San Diego, microfiche.

Hides, J.G. 1936. Papuan Wonderland. London: Blackie \& Son.

Hogbin, Ian H. 1947. "Native Christianity in a New Guinea Village.” Oceania 18 (1): 1-35. doi:10.1002/j.1834-4461.1947.tb00458.x. 
Hogbin, Ian H. 1951. Transformation Scene: The Changing Culture of a New Guinea Village. London: Routledge \& Kegan Paul Limited.

Hogbin, Ian H. 1963. Kinship and Marriage in a New Guinea Village. London: The Athlone Press.

Højer, Lars, Anja Kublitz, Stine Simonsen Puri, and Andreas Bandak. 2018. "Escalations: Theorizing Sudden Accelerating Change.” Anthropological Theory 18 (1): 36-58. doi:10.1177/1463499617744142.

Kituai, August Ibrum K. 1998. My Gun, My Brother: The World of the Papua New Guinea Colonial Police, 1920-1960. Honolulu: University of Hawai‘i Press.

Lahui, Jack. 1975. Gamblers Niugini Style: Poems by Jack Lahui. Port Moresby: Papua Pocket Poets.

Laycock, Donald. 1966. "Three Native Card Games of New Guinea and their European Ancestors." Oceania 37 (1): 49—53. doi: 10.1002/j.1834-4461.1966.tb00879.x.

Laycock, Donald. 1967. "Three More New Guinean Card Games, and a Note on "Lucky"." Oceania 38 (1): 51-55. doi:10.1002/j.1834-4461.1967.tb00934.x.

Laycock, Donald. 1972. "Gambling.” In Encyclopaedia of Papua New Guinea. Edited by Peter Ryan, 475-478. Carlton (Australia): Melbourne University Press.

Mair, L.P. 1948. Australia in New Guinea. London: Christophers.

Mead, Margaret. 1956. New Lives for Old: Cultural Transformation - Manus, 1928-1953.

New York: William Morrow and Company.

Mead, Margaret. (1968) 2002. The Mountain Arapesh. New Brunswick (New Jersey): Transaction Publishers.

Memorandum C.A. 37/2/3 12 $12^{\text {th }}$ Jan 1954.

Mosko, Mark S. 2012. “Laki Charms: 'Luck' and Personal Agency in North Mekeo Social Change." Social Analysis 56 (2): 19-38. doi:10.3167/sa.2012.560203.

Murray, Sir Hubert. 1925. Papua of Today: Or an Australian Colony in the Making. London: P.S. King \& Son, Ltd.

Pickles, Anthony J. 2014a. "Gambling Futures: Playing the Imminent in Highland Papua New Guinea.” In Pacific Futures: Projects, Politics and Interests, edited by Will Rollason, 96-113. New York: Berghahn.

Pickles, Anthony J. 2014b. “Introduction: Gambling as Analytic in Melanesia.” Oceania 84 (3): 207-221. doi:10.1002/ocea.5057 
Pickles, Anthony J. 2019. Money Games: Gambling in a Papua New Guinea Town. New York: Berghahn Books.

O'Hara, John. 1988. A Mug's Game: A History of Gaming and Betting in Australia. Sydney: UNSW Press.

Reefe, Thomas Q. 1987. “The Biggest Game of All: Gambling in Traditional Africa.” In Sport in Africa: Essays in Social History, edited by William J. Baker \& James A. Mangan, 47-78. Africana Publishing Company: New York.

Schwartz, David G. 2006. Roll the Bones: The History of Gambling. London: Gotham Books.

Seligman, C.G. 1910. The Melanesians of British New Guinea. Cambridge: Cambridge University Press.

Strathern, Marilyn. 1999. Property, Substance and Effect: Anthropological Essays on Persons and Things. London: Athlone Press.

Territory of Papua and New Guinea House of Assembly Debates (TPNGHAD) 1:6. 1965. 24 ${ }^{\text {th }}$ August to $3^{\text {rd }}$ December 1965.

Territory of Papua and New Guinea House of Assembly Debates Second House (TPNGHADSH) 2:5. 1969. 16 $6^{\text {th }}$ June to $27^{\text {th }}$ June 1969.

Watson, R.S., 1971. Special Patrol Report to the Gadsup and Agarabi Census Divisions. Patrol Report No.9 of 1971-2. Mandeville Special Collections Library, University of California San Diego, microfiche.

Wolfers, Edward P. 1975. Race Relations and Colonial Rule in Papua New Guinea. Sydney: Australia and New Zealand Book Company. 

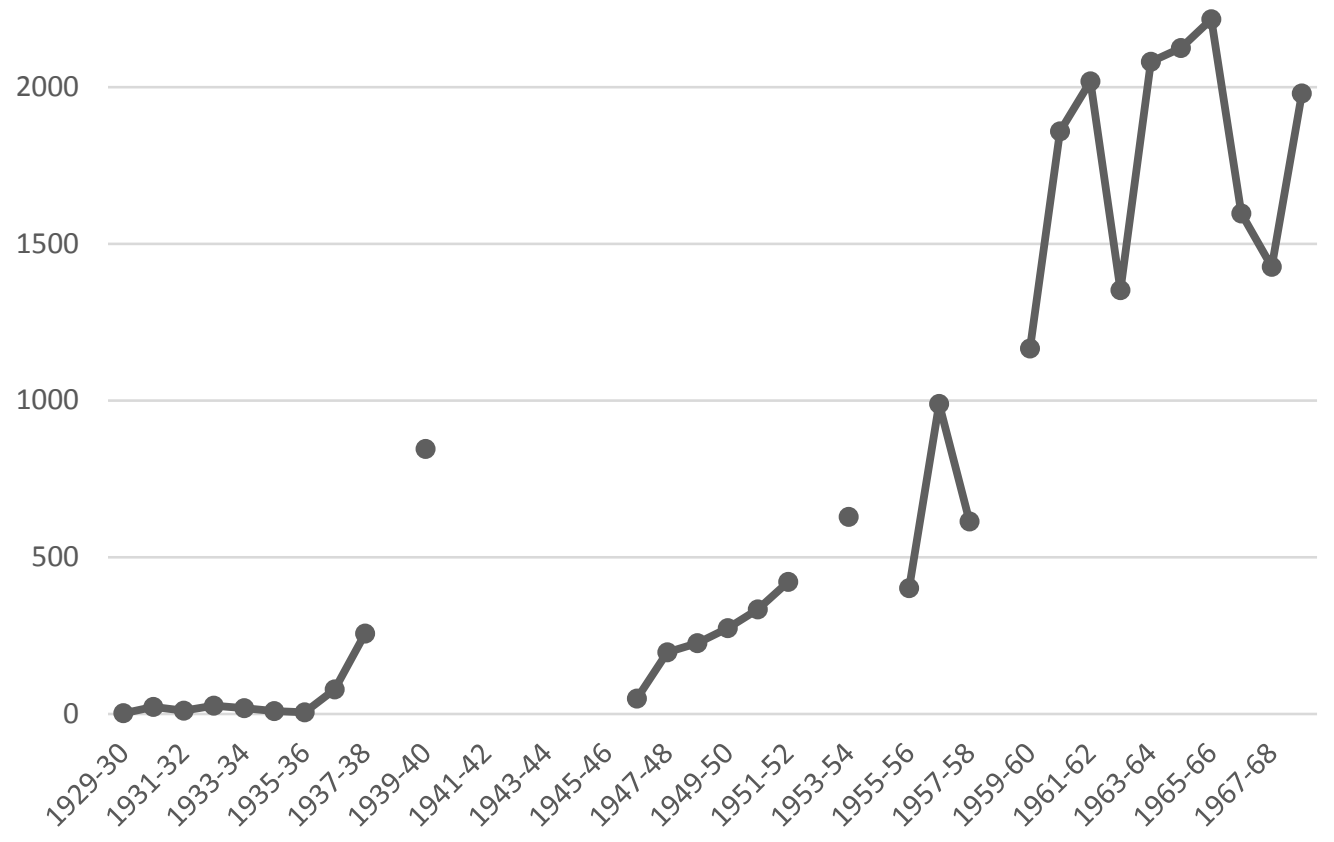

Chart 1: Gambling convictions of ethnic New Guineans in New Guinea for the period 19291968 for years that data could be obtained. ${ }^{\text {ii }}$ 
Map 1: References to the presence of gambling found by the author for the period up to 1940.

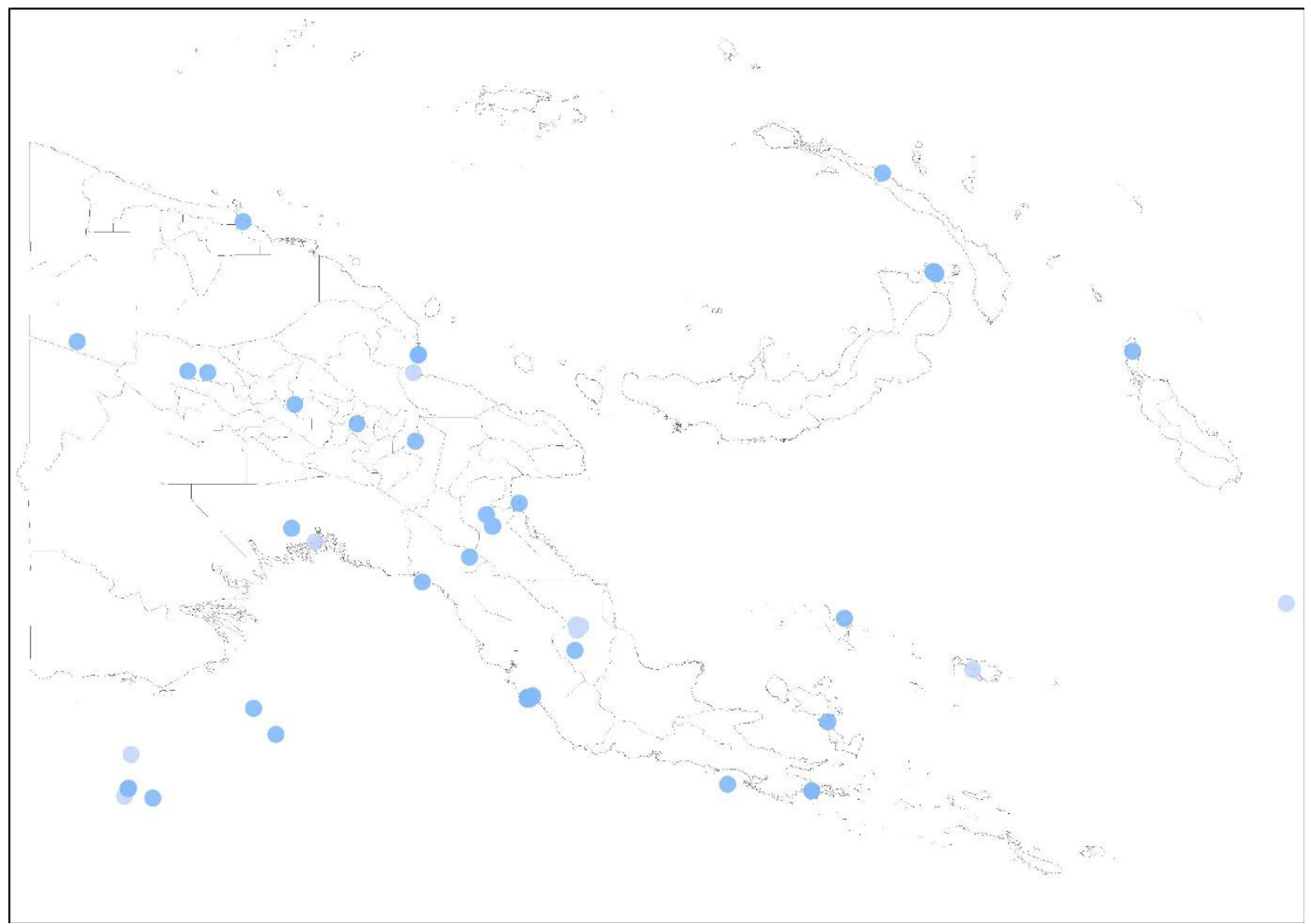


Map 2: References to the presence of gambling found by the author for the period up to 1980.

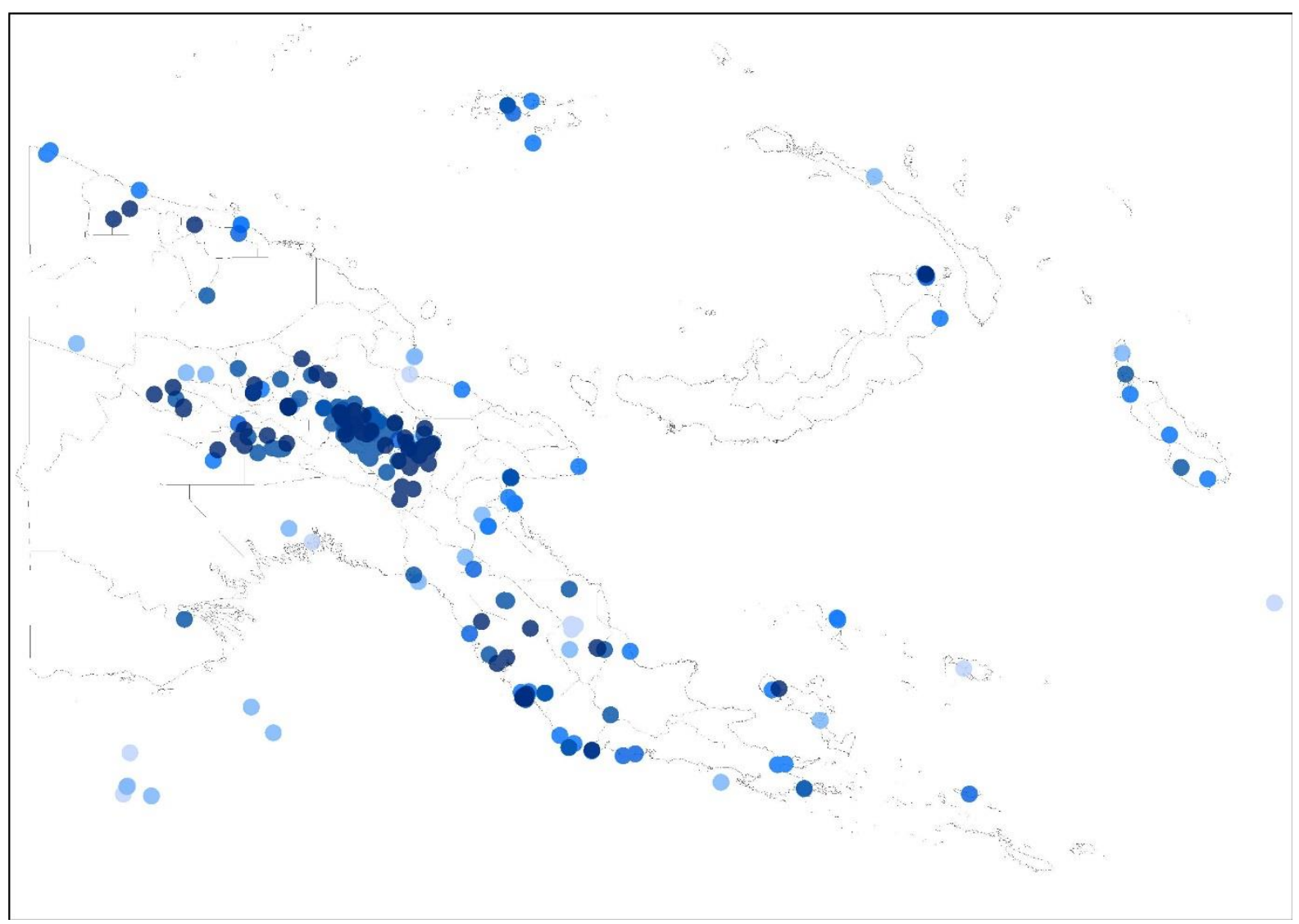

Map 3: References to the presence of gambling in the PNG Highlands found by the author for the period up to 1970 superimposed upon the road network as it was in 1970. 


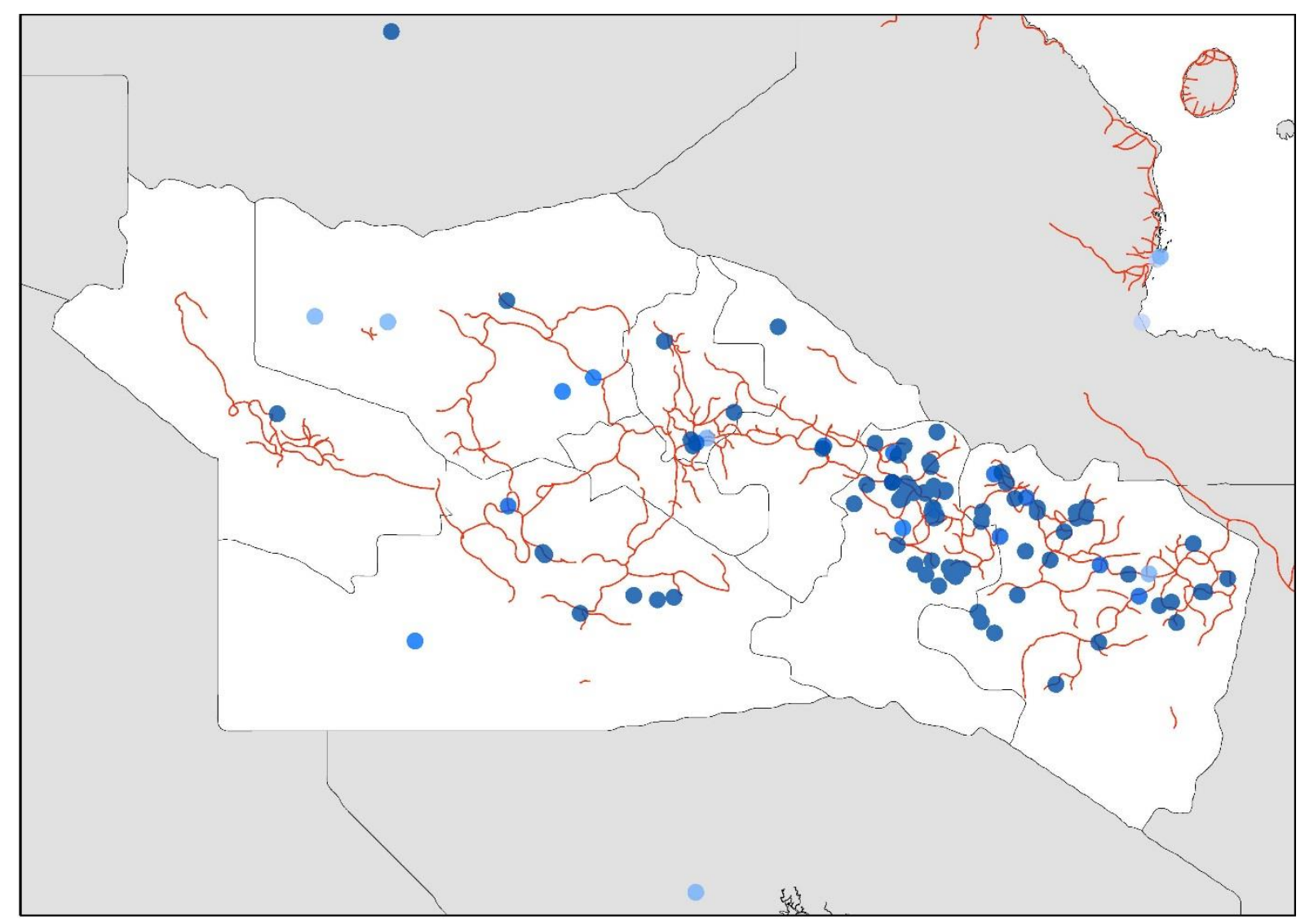

${ }^{i}$ Sufficient records for Papua were not found.

ii CARCLNATNG 1929-30 to 1967-8. 